\title{
The current practices of intervention with batterers
}

\author{
Uma revisão das práticas atuais na intervenção com agressores conjugais
}

\author{
Olga Cunha', Ruı Abrunhosa Gonçalves ${ }^{1}$ \\ ${ }^{1}$ School of Psychology, University of Minho, Braga, Portugal.
}

Received: 1/30/2014 - Accepted: 5/12/2014

DOI: $10.1590 / 0101-60830000000008$

\begin{abstract}
Background: Since the 70s there was a proliferation of intervention programs for batterers; however the results remain controversial. Objectives: This study aims to analyse the literature published between the years of 2000 and 2013 about the effectiveness of the intervention with batterers. Methods: A review of papers about intervention with batterers published during this period (2000-2013) was conducted. Social sciences databases were checked. Papers about programs for a specific public or programs with a broad intervention focus, and with female and homosexual offenders were excluded. Results: Thirty-six studies that described 37 intervention programs fulfilled the inclusion criteria. In general, the analysed programs adopted a group format (70.3\%) and a cognitive-behavioural (56.8\%) or psychoeducational (18.9\%) intervention model (32.4\% assumed to adopt a Duluth model). Concerning the effectiveness, results showed success rates of 39.4\%-97\%, dropout rates of 10\%-58\% and recidivism rates of 0\%-65.9\%. Discussion: The effectiveness of intervention with batterers remains controversial, which seems to be due to the different methodologies used in the studies. Despite the inconsistencies, programs for perpetrators are an important way to reduce intimate partner violence recidivism.
\end{abstract}

Cunha O, Gonçalves RA / Rev Psiq Clín. 2014;41(2):40-8

Keywords: Intimate partner violence, batterers, intervention programs, intervention efficacy.

\section{Resumo}

Contexto: Desde os anos 1970, assiste-se a uma proliferação dos programas de intervenção para agressores conjugais, no entanto os resultados mantêm-se controversos. Objetivos: Este estudo visa analisar a literatura publicada entre os anos de 2000 e 2013 acerca da eficácia da intervenção com agressores conjugais. Métodos: Para o efeito, realizou-se uma revisão de artigos publicados durante esse período (2000-2013) a respeito da intervenção com agressores conjugais. Foram consultadas bases de dados de referência na área das ciências sociais. Excluíram-se da análise artigos que versavam sobre programas destinados a um público-alvo ou com um foco de intervenção demasiadamente amplo, agressoras do sexo feminino e agressores homossexuais. Resultados: Trinta e seis estudos que descreviam 37 programas de intervenção dirigidos a agressores conjugais preencheram os critérios de inclusão definidos. Na generalidade, os programas analisados adotaram um formato grupal (70.3\%) e um modelo de intervenção cognitivo-comportamental (56,8\%) e/ou psicoeducativo $(18,9 \%)$, e uma parte se assumiu como assente no modelo Duluth $(32,4 \%)$. No que diz respeito à eficácia da intervenção, os resultados dos diferentes estudos revelaram-se ambíguos, com taxas de sucesso entre os $39,4 \%$ e os $97 \%$, taxas de abandono entre os $10 \%$ e os $58 \%$ e taxas de reincidência entre os $0 \%$ e os 65,9\%. Conclusão: Em suma, a eficácia da intervenção com agressores conjugais mantém-se controversa, o que parece relacionar-se essencialmente com as diferentes metodologias utilizadas nos estudos. Não obstante tais inconsistências, os programas para agressores revelam-se uma importante medida na redução da reincidência na violência doméstica.

Cunha O, Gonçalves RA / Rev Psiq Clín. 2014;41(2):40-8

Palavras-chave: Violência em relações de intimidade, agressores conjugais, programas de intervenção, eficácia da intervenção.

\section{Introduction}

Intimate partner violence (IPV) is a serious public health problem, associated with severe physical, mental/psychological, sexual, reproductive and social consequences ${ }^{1-3}$. Women victims of IPV usually suffer violent deaths, either direct (e.g. homicide) or indirect (e.g. suicide, HIV $)^{4}$. IPV is also associated with other health risk factors, such as alcohol and drug abuse, and unprotected $\operatorname{sex}^{2}$. In this sense, IPV results in high economic costs, including the costs associated with health services and legal procedures ${ }^{4}$.

Prevalence data estimate that $15 \%$ to $71 \%$ of women have reported physical and/or sexual violence by an intimate partner at some point of their lives 5 . Additionally, a recent systematic review revealed that $30 \%$ of all the women around the world and $25.3 \%$ of the European women experienced physical and/or sexual violence by an intimate partner throughout their life ${ }^{6}$. A survey conducted in Portugal in 2007 revealed that $38.1 \%$ of women have experienced, at least, one episode of physical, emotional and/or sexual violence?

This scenario led to the adoption of social and legal measures, among which intervention programs for batterers are included. Although initially the intervention was directed to the victims only, in
70 s a paradigmatic change has occurred, beginning the intervention with offenders ${ }^{8-10}$. The feminist movements were preponderant by the visibility that they gave to the phenomenon, making aware the need for batterer's intervention, since until then the mental health system provided scarce options to that problem ${ }^{11}$. Additionally, the professionals who worked with the victims faced up to a climate of frustration because they noted that the intervention directed exclusively to the victim did not prove effective, either by the inability of many of the women to break with the violence or by the fact that these women do not seek alternative solutions for their condition $^{12}$. The professionals also faced the fact that a great part of women in shelters wanted to return to their abusive husbands or did not want to break up with the relationship ${ }^{13,14}$ and that abusive men tended to engage continuously in abusive relationships ${ }^{13}$.

These intervention programs had as main goal the end of the abusive behaviours through the awareness of equality in intimate relationships and men accountability for his violence; and violence was conceptualized as an instrumental and intentional action ${ }^{11}$. Despite its innovative nature, the first programs reproduced some of the limitations from the mental health approach, not advocating the contact with the justice system ${ }^{11}$. Given these limitations other programs emerged in which the goal was to expand its action 
and match the intervention to the social reality. The development of coordinated community responses, structured curricula and intervention standards contributed to its proliferation ${ }^{11}$, being batterer intervention programs just an element of that response ${ }^{8}$. However, in practice many of these responses were not real coordinated community responses ${ }^{11}$. In this context, a third wave of intervention programs that attempted to extend the scope of its action emerged, maintaining a focus on accountability and in the learning of nonabusive relationships ${ }^{11}$.

The different waves of batterer intervention programs contributed to the reduction and/or ending of abusive behaviour in many intimate relationships, so today, the references to intervention programs are extensive. The referral of batterers to intervention programs acts as an alternative sanction to prison ${ }^{15}$ and, simultaneously, allows the breaking of the cycle of violence and guarantees victims safety ${ }^{16}$.

Nevertheless the wide expansion of these programs, data concerning its efficacy remains controversial ${ }^{13,17,18}$. Regarding this subject research shows that some intervention programs have dropout rates around $50 \%$ and that many men that attend intervention programs continue to show high levels of resistance to change ${ }^{19}$. At the same time, literature indicates that batterers who do not complete the programs present a higher likelihood of re-offense than those who complete the intervention ${ }^{20}$.

In fact, effectiveness assessments revealed a difficult process due to methodological, ethical and practical issues. It is known that different theoretical approaches, designs and statistical analysis can produce unequal results. Additionally, similar programs with different participants in different contexts can also generate dissimilar results ${ }^{21}$.

Therefore, in order to know the efficacy of the intervention with batterers a review of experimental, quasi-experimental and post-facto studies that assessed the efficacy of such programs was performed.

\section{Methods}

In the present study a systematic search of publications assessing batterers' treatment programmes efficacy from 2000 to 2013 was conducted. The choice for this time gap was based in two factors: (1) to obtain a sufficiently wide and current sample of the existent programs; and (2) to fulfil the constraints of previous meta-analysis and systematic literature reviews on this matter that mainly focused on recidivism or re-offense rates to assess intervention programs efficacy ${ }^{13,17,18,22,23}$. With this purpose, social sciences data bases of higher visibility were consulted: ScienceDirect, Springer, Taylor \& Francis, Wiley, SAGE, PsycINFO, PsycARTICLES, ERIC - Educational Resources Information Centre, ISI Web of Knowledge, NCJRS - National Criminal Justice Reference Service. For this research was used a combination of the following concepts/ key-words: "intimate partner violence", "domestic violence", "marital violence", "spouse abuse", "batterer, marital offender", "intervention", "program". In a first phase, were analysed the titles and abstracts of papers that described interventions with batterers. In a second moment, were selected two typologies of papers: (a) empirical papers that described the assessment of intervention programs for male perpetrators of violence on heterosexual intimate relationships and (b) literature reviews and meta-analysis about intervention programs with batterers. In a third phase, were analysed the references of the selected material and identified other relevant texts. In the analysis only publications from journals with blind peer review were included.

The articles retrieved from the database search should meet the following criteria: (a) intervention programs directed to heterosexual male batterers; (b) report results about intervention effectiveness in at least one dimension (e.g., recidivism, i.e. official reports, couple reports and/or aggressor self-reports; psychopathology, i.e. depression, anxiety; violence perpetration; aggression; impulsivity; dropout rates; completion rates); (c) describe the treatment theoretical approach, contents, aims and duration of the intervention program; and (d) measure changes in some dimension during the postintervention and/or follow-up period. In the analysis, papers that compared different programs written in English, Portuguese and Spanish were also included.

From the analysis were excluded: (a) intervention programs for women or homosexuals; (b) programs addressed to a specific target group (e.g. African Americans, war veterans); (c) programs with a wide intervention focus (e.g. substances abuse); (d) editorial, papers on congresses, book chapters and dissertations; and (e) papers that included in the sample different intervention programs, without an individualized assessment.

The data about the selected papers/programs were analysed using a protocol that include the following variables: (1) general issues: year of publication, service/centre and country responsible for the program implementation; (2) program curriculum: objectives, intervention strategies and methods, theoretical approach, duration, program content and intervention format; (3) methodology and program efficacy: design, assessment dimensions, assessment moments and intervention results.

All the papers were analysed and coded independently by two reviewers. The disagreements among reviewers were solved through consensus.

\section{Results}

Through the analysis of scientific data bases 881 papers were identified (Figure 1). Among them, 337 were repeated and were excluded from the analysis. From the 544 abstracts considered, 171 were excluded. Three hundred and seventy-three complete papers were analysed, being 337 papers excluded based on the exclusion-

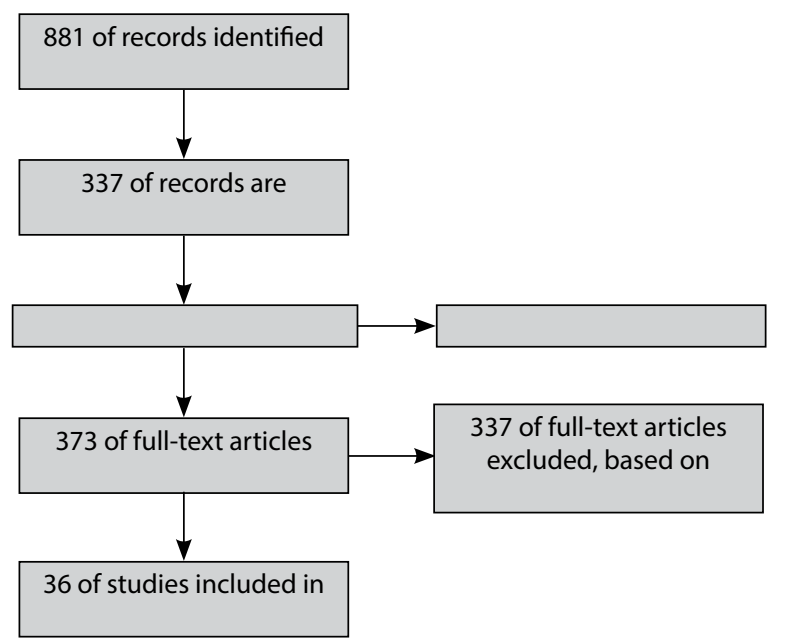

inclusion criteria described in the methods section. In total, 36 papers that described 37 intervention programs for batterers ${ }^{(1)}$ were identified.

\section{General issues}

The most part of the papers included in the qualitative syntheses was published in $2006(\mathrm{n}=7 ; 19.4 \%), 2009(\mathrm{n}=5 ; 13,9 \%)$ and $2013(\mathrm{n}=3 ; 8,3 \%)$.

Regarding the 37 intervention programs, results revealed that the generality took place in domestic violence centres/batterer intervention agencies $(\mathrm{n}=17 ; 45.9 \%)$. Notwithstanding, prisons $(n=5 ; 13.5 \%)$, probation services $(n=4 ; 10.8 \%)$, child protection services $(n=1 ; 2.7 \%)$, hospitals $(n=1 ; 2.7 \%)$ and Universities $(n=$ 1 In the selected papers there were repeated programs. Note that $R \& R^{24}$ program was not exclusively for batterers. 
$1 ; 2.7 \%$ ) were also responsible for the implementation of intervention programs.

The most part of the programs was developed in the United States of America (USA) $(\mathrm{n}=19 ; 51.35 \%)$, however, intervention programs were also found in Spain $(n=7 ; 18.9 \%)$, Canada $(n=4$; $10.8 \%)$, England $(\mathrm{n}=1 ; 2.7 \%)$, China $(\mathrm{n}=1 ; 2.7 \%)$ and Taiwan $(\mathrm{n}=1 ; 2.7 \%)$

\section{Program curriculum}

The objectives most reported in the programs were: skills promotion $(\mathrm{n}=12 ; 36.1 \%) ;$ anger/self-control decrease $(\mathrm{n}=7 ; 22.2 \%)$; educating about domestic violence $(n=6 ; 16.7 \%)$; ending the abusive behaviour $(n=5 ; 13.9 \%)$; accountability for violence $(n=5 ; 13.9 \%)$; and reduction of cognitive distortions towards gender roles and violence use $(\mathrm{n}=3 ; 11.1 \%)$. Goals such as motivation to change ( $\mathrm{n}$ $=3 ; 8.3 \%)$, equality promotion $(\mathrm{n}=2 ; 5.5 \%)$, recidivism reduction $(\mathrm{n}=2 ; 5.5 \%)$ and relapse prevention $(\mathrm{n}=2 ; 5.5 \%)$ were also found. Among the selected programs, only 20 (54\%) listed the objectives.

Regarding the theoretical approach, the most part of the programs clarify this question, being the cognitive-behavioural model $(n=21$; $56.8 \%)$, the psychoeducational model $(\mathrm{n}=7 ; 18.9 \%)$, the feminist approach $(\mathrm{n}=2 ; 5.4 \%)$ and the motivational interview $(\mathrm{n}=3$; $8.1 \%$ ) the most common. Among them, a considerable number of programs defined their intervention as based on the Duluth model $(\mathrm{n}=12 ; 32.4 \%)$ and $9(24.3 \%)$ programs showed a combination of at least two intervention models. Additionally, psychodynamic programs were found $(\mathrm{n}=1 ; 2.7 \%)$, as well as couples therapy $(\mathrm{n}=$ $1 ; 2.7 \%)$, ecological model $(\mathrm{n}=1 ; 2.7 \%)$ and support groups $(\mathrm{n}=$ $1 ; 2.7 \%$ ). Finally, the program described by Pascual-Leone et al. ${ }^{25}$ presented a combination of different approaches: emotion-focused therapy, eye movement desensitization and reprocessing and imago couples therapy.

Despite some differences, the contents of the intervention programs were quite similar. Therefore, the most part of the programs had an informative component about domestic violence concept and nature $(\mathrm{n}=16 ; 43.2 \%)$, interpersonal skills promotion $(\mathrm{n}=15$; $40.5 \%$ ) and a module about attitudes towards women and the use of violence in intimate relationships $(\mathrm{n}=14 ; 37.8 \%)$. The accountability for abusive behaviours $(\mathrm{n}=11 ; 29.7 \%)$, anger/emotions management $(\mathrm{n}=11 ; 29.7 \%)$, motivation to change $(\mathrm{n}=8 ; 21.6 \%)$ and substance abuse $(n=4 ; 10.8 \%)$ were also contents included in the identified programs.

In the programs, a wide variety of strategies and intervention methods was verified, however, in $14(37.8 \%)$ programs there was not any reference to them. The main strategies used in the different programs were time-out $(\mathrm{n}=12 ; 32.4 \%)$, cognitive restructuring $(\mathrm{n}=12 ; 32.4 \%)$, self-instructions $(\mathrm{n}=6 ; 16.2 \%)$, skills training $(\mathrm{n}$ $=5 ; 13.5 \%)$, muscular relaxing $(\mathrm{n}=5 ; 13.5 \%)$, feedback $(\mathrm{n}=4$; $10.8 \%)$, problem solving training $(\mathrm{n}=2 ; 5.4 \%)$, ABC model $(\mathrm{n}=$ $2 ; 5.4 \%)$, cognitive distractions $(\mathrm{n}=2 ; 5.4 \%)$ and active listening $(\mathrm{n}=2 ; 5.4 \%)$. In the methods applied, the role-play $(\mathrm{n}=6 ; 16.2 \%)$, the homework $(n=6 ; 16.2 \%)$, the videos $(n=5 ; 13.5 \%)$, the power and control wheel $(n=2 ; 5.4 \%)$, the violence cycle $(n=1 ; 2.7 \%)$, the equality wheel $(n=1 ; 2.7 \%)$ and the brainstorming $(n=1 ; 2.7 \%)$ were identified. Other programs also used behavioural contracts (n $=1 ; 2.7 \%)$ and individual safety plans $(\mathrm{n}=1 ; 2.7 \%)$.

The information available concerning program duration did not allow analysing correctly this data, since time unity varied between hours, weeks, years and number of sessions. Nevertheless, sessions varied between a minimum of 7 and a maximum of 75; and the number of weeks varied between a minimum of 12 and a maximum of 26 . In some cases the program lasted two years ${ }^{26}$. The most part of the programs worked in a weekly basis $(\mathrm{n}=13 ; 35.1 \%)$. The sessions varied between $1(n=2 ; 5.4 \%)$ and 5 hours $(n=1 ; 2.7 \%)$, although, the majority lasted two hours $(\mathrm{n}=13 ; 35.1 \%)$.

Considering the intervention format, the most part of the programs adopted a group format $(n=26 ; 70.3 \%)$. Notwithstanding, individual $(n=1 ; 2.7 \%)$ and couples interventions $(n=2 ; 5.4 \%)$ were also found; 6 (16.2\%) programs used both formats.

\section{Method and program efficacy}

From what was possible to analyse, the assessment focus of the different studies was very diverse, according to the objectives previously outlined to each program. Among the assessed parameters, it can be highlighted the recidivism $(n=17 ; 47.2 \%)$, the success rates $(\mathrm{n}=12 ; 33.3 \%)$, the abusive behaviour against the victim $(\mathrm{n}=15$; $41.6 \%$ ), the attitudes toward women and towards the use of violence (n $=8 ; 22.2 \%)$, the accountability for abusive behaviour $(\mathrm{n}=7 ; 19.4 \%)$, the psychological psychopathology $(n=5 ; 13.9 \%)$, the self-esteem ( $n$ $=5 ; 13.9 \%)$, the anger $(\mathrm{n}=5 ; 13.9 \%)$ and the motivation to change $(\mathrm{n}=4 ; 11.1 \%)$. In the same way, and at a lower expression, other dimensions assessed were observed, namely jealousy $(n=3 ; 8.3 \%)$, aggression $(\mathrm{n}=3 ; 8.3 \%)$, therapeutic environment $/$ cohesion $(\mathrm{n}=$ $2 ; 5.5 \%)$, substance abuse $(\mathrm{n}=1 ; 2.8 \%)$, emotional dependency $(\mathrm{n}$ $=1 ; 2.8 \%)$, locus of control $(\mathrm{n}=1 ; 2.8 \%)$, moral reasoning $(\mathrm{n}=1$; $2.8 \%$ ), among others.

From the 37 studies analysed (Tables 1 and 2) the most part identified the design as quasi experimental $(\mathrm{n}=27 ; 73 \%)$; however the experimental $(\mathrm{n}=3 ; 8.1 \%)$ the randomized $(\mathrm{n}=2 ; 5.4 \%)$ and the post-facto $(\mathrm{n}=1 ; 2.7 \%)$ experiments were also found.

The intervention effectiveness was analysed by applying different measures in different moments: pre-intervention (pre-test) $(\mathrm{n}=26 ; 72.2 \%)$, post-intervention (post-test) $(\mathrm{n}=26 ; 72.2 \%)$ and follow-up $(n=16 ; 44.4 \%)$. It is, however, important to note that in 18 $(50 \%)$ studies subjects were only assessed in pre- and post-test and in $8(22.2 \%)$ only in the follow-up. After analysing the duration of the follow-up period, a significant discrepancy between a minimum of 1 month and a maximum of 3 years was found. Nevertheless, a prevalence of $6(n=9 ; 25 \%)$ and $12(n=11 ; 30.6 \%)$ months followup assessments was observed. Among the papers analysed only $8(22.2 \%)$ presented a control group and $14(38.9 \%)$ presented a comparison group, in many cases composed by the individuals who dropped out or by a group of individuals referenced in a different intervention.

To what concerns the results of individual studies (i.e. 30 studies), $21(70 \%)$ revealed positive results in at least one of the assessed dimensions. However, the inclusion of a control group in only $5(16.7 \%)$ of this studies constrained an effective assessment of changes. On the other hand, $9(30 \%)$ studies did not show significant differences between the different assessment moments.

In general, the studies (individual and comparative studies) revealed success rates that varied between $39.4 \%$ and $97 \%$. The dropout rates were between $10 \%$ and $58 \%$. Concerning recidivism, the results were quite variable, ranging between $0 \%$ and $65.9 \%$. The different studies also revealed positive changes in the perpetration of violence against the intimate partner $(n=11 ; 30.6 \%)$, attitudes toward violence and/or toward women $(n=9 ; 25 \%)$, anger $(n=5$; $13.9 \%)$, psychological symptomatology $(n=5 ; 13.9 \%)$, self-esteem $(\mathrm{n}=4 ; 11.1 \%)$, acceptance of responsibility for violence $(\mathrm{n}=4$; $11.1 \%)$, motivation to change $(n=4 ; 11.1 \%)$, aggression $(n=3$; $8.3 \%)$, jealousy $(n=3 ; 8.3 \%)$, empathy $(n=2 ; 5.6 \%)$, empathy for the victim $(n=2 ; 5.6 \%)$, impulsivity $(n=2 ; 5.6 \%)$, hostility $(n=2$; $5.6 \%)$, marital satisfaction $(\mathrm{n}=2 ; 5.6 \%)$, among others.

The studies that adopted intervention models different from the cognitive behavioural, the psychoeducational or the combination of both ${ }^{25,43,53}$, revealed positive results. For instance, the study of Lawson et al. $^{43}$, that employed an intervention program based on cognitive behavioural and psychodynamic models, showed an increase in attachment and in global functioning and a decrease in anxiety and depressive symptoms and in violence against the partner or ex-partner. The study conducted by Stith et al..$^{50}$, based on couples therapy, also revealed that subjects who participated in the intervention positively changed attitudes towards violence, marital satisfaction and abusive behaviours. Lastly, the research conducted 
Table 1. Research design and intervention programs results

\begin{tabular}{|c|c|c|}
\hline Authors & Research design & Results \\
\hline $\begin{array}{l}\text { Bowen }^{27(1)} \text { (Domestic } \\
\text { Violence Perpetrator } \\
\text { Program - DVPP) }\end{array}$ & $\begin{array}{l}\text { Quasi-experimental } \\
\text { (pre-test, post-test and } 5 \text { months follow-up) } \\
\mathrm{G} 1=2 \text { hours } \\
\mathrm{G} 2=2.5 \text { hours }\end{array}$ & $\begin{array}{l}\text { Group cohesion }(+) \text {; Leaders support }(+) \\
\text { Expressiveness: } \mathrm{G} 1^{* *}(+) \\
\text { Anger and aggression: } \mathrm{G} 1^{* *}(+) \\
\text { Order and organization: } \mathrm{G} 2^{*}(+) \\
\text { Leader control: } \mathrm{G} 2^{* * *}(+) ; \text { Innovation: } \mathrm{G} 1^{* *}(+)\end{array}$ \\
\hline $\begin{array}{l}\text { Bowen et al.20(1) } \\
\text { (Domestic Violence } \\
\text { Perpetrator Program } \\
\text { - DVPP) }\end{array}$ & $\begin{array}{l}\text { Quasi-experimental } \\
\text { (pre-test, post-test and } 11 \text { months follow-up) } \\
\text { G1 = completers } \\
\text { G2 = dropout }\end{array}$ & $\begin{array}{l}\text { Dropout }=33 \% \\
\text { Re-offending }=21 \% \\
\text { Demographic characteristics: G1 x G2: } \mathrm{ns} \\
\text { Psychological characteristics: G1 x G2: } \mathrm{ns} \\
\text { Criminal history characteristics: } \mathrm{G} 1 \text { x G2 } 2^{* *}(+)\end{array}$ \\
\hline $\begin{array}{l}\text { Bowen et al.28(1) } \\
\text { (Domestic Violence } \\
\text { Perpetrator Program } \\
\text { - DVPP) }\end{array}$ & $\begin{array}{l}\text { Quasi-experimental } \\
\text { (pre-test, post-test and } 5 \text { month follow-up) } \\
\text { GN = non-offenders } \\
\text { GO = offenders }\end{array}$ & $\begin{array}{l}\text { Re-offending }=10.8 \% \\
\text { Cognitive domain, arousal domain, behavioural domain, sympathy for } \\
\text { the battered women, chance locus of control: GN x GO: ns }\end{array}$ \\
\hline Buttell ${ }^{29}$ & $\begin{array}{l}\text { Quasi-experimental } \\
\text { (pre-test and post-test) }\end{array}$ & Moral reasoning: $\mathrm{ns}$ \\
\hline Buttell and Carney ${ }^{30(2)}$ & $\begin{array}{l}\text { Quasi-experimental } \\
\text { (pre-test and post-test) }\end{array}$ & $\begin{array}{l}\text { Spouse-specific behaviour, controlling behaviour and propensity for } \\
\text { abuse: } n s\end{array}$ \\
\hline Buttell and Carney ${ }^{31(3)}$ & $\begin{array}{l}\text { Quasi-experimental } \\
\text { (pre-test and post-test) } \\
\text { G1 = African American } \\
\text { G2 = Caucasian }\end{array}$ & $\begin{array}{l}\text { Passive-aggressive responses }{ }^{* * *}(-) \\
\text { Assertiveness, controlling behaviour, propensity for abuse: } n s \\
\text { G1 x G2: ns }\end{array}$ \\
\hline Buttell and Carney ${ }^{32(2)}$ & $\begin{array}{l}\text { Quasi-experimental } \\
\text { (pre-test and post-test) } \\
\text { G1 = African American } \\
\text { G2 = Caucasian }\end{array}$ & $\begin{array}{l}\mathrm{G} 1=\text { Self-deception } \\
\mathrm{G} 2=\text { Propensity for abusiveness }^{* * *}(+) \\
\text { Total sample } \\
\text { Passive-aggressive responses } \\
\text { propensity for abusiveness }^{* *}(-)\end{array}$ \\
\hline Buttell and Pike ${ }^{33}$ & $\begin{array}{l}\text { Quasi-experimental } \\
\text { (pre-test, post-test and } 12 \text { months follow-up) }\end{array}$ & $\begin{array}{l}\text { Success }=72.5 \% \\
\text { Alcohol** }(-) ; \text { Drug } \\
\text { Control* }(-) \text {; Violence }(-) ; \text { Stress-coping } \\
\text { (** }(-)\end{array}$ \\
\hline Carney and Buttell ${ }^{34(3)}$ & $\begin{array}{l}\text { Quasi-experimental } \\
\text { (pre-test and post-test) }\end{array}$ & $\begin{array}{l}\text { Dropout }=58 \\
\text { Interpersonal dependency: } \mathrm{ns}\end{array}$ \\
\hline Chan $^{35}$ & $\begin{array}{l}\text { Quasi-experimental } \\
\text { (pre-test and post-test) }\end{array}$ & $\begin{array}{l}\text { Physical assault* (-) } \\
\text { Psychological aggression* }(-)\end{array}$ \\
\hline $\begin{array}{l}\text { Cissner and } \\
\text { Puffett }^{36} \text { (The } \\
\text { Domestic Violence } \\
\text { Accountability } \\
\text { Program) } \\
\end{array}$ & 1 year follow-up & $\begin{array}{l}\text { Success }=68 \% \\
\text { Recidivism: in-program arrest }=27 \% ; 1 \text { year post sentence arrest }=27 \% ; 1 \\
\text { year post-program arrest }=18 \% \\
\text { Criminal contempt arrest }=7 \% \\
\text { Violent arrest }=12 \%\end{array}$ \\
\hline $\begin{array}{l}\text { Cissner and Puffett }{ }^{36} \\
\text { (Interborough } \\
\text { Developmental } \\
\text { Consultation Centre } \\
\text { - IDCC) }\end{array}$ & 1 year follow-up & $\begin{array}{l}\text { Success }=77 \% \\
\text { Recidivism: in program arrest }=29 \% ; 1 \text { year post sentence arrest }=36 \% ; 1 \\
\text { year post program arrest }=14 \% \\
\text { Criminal contempt arrest }=14 \% \\
\text { Violent arrest }=16 \%\end{array}$ \\
\hline $\begin{array}{l}\text { Connors et al. } .^{37} \text { (The } \\
\text { Moderate Intensity } \\
\text { Family Violence } \\
\text { Prevention Program) }\end{array}$ & $\begin{array}{l}\text { Quasi-experimental } \\
\text { (pre-test and post-test) } \\
\text { G1 = Ready to change } \\
\text { G2 = Not ready }\end{array}$ & 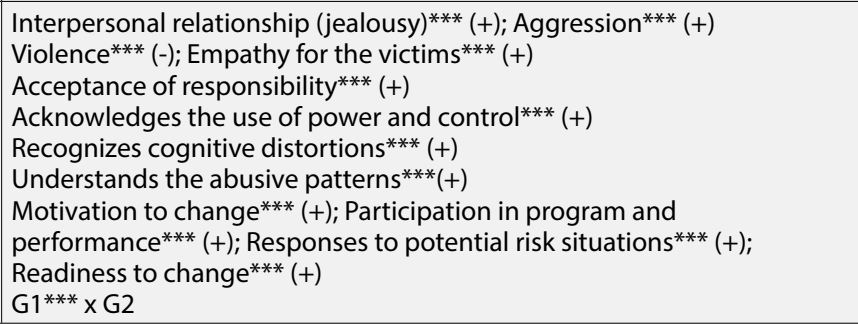 \\
\hline $\begin{array}{l}\text { Connors et al. }{ }^{38} \text { (The } \\
\text { High Intensity Family } \\
\text { Violence Prevention } \\
\text { Program) }\end{array}$ & $\begin{array}{l}\text { Quasi-experimental } \\
\text { (pre-test and post-test) }\end{array}$ & 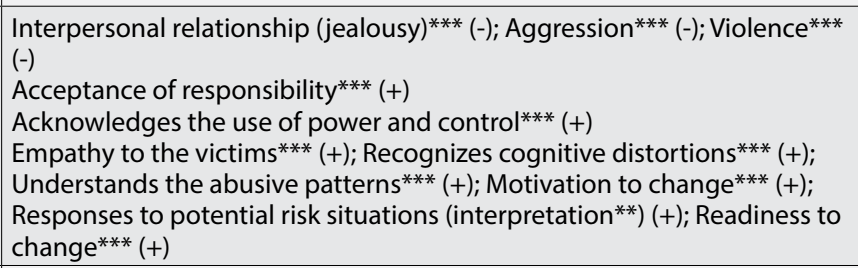 \\
\hline \begin{tabular}{|l|} 
Echeburúa and \\
Fernández-Montalvo ${ }^{39}$ \\
(4)
\end{tabular} & $\begin{array}{l}\text { Quasi-experimental } \\
\text { Pre-test } \\
\text { Post-test }\end{array}$ & $\begin{array}{l}\text { Success: } 68.2 \% \\
\text { Cognitive bias about women }{ }^{* *}(-) ; \text { Cognitive bias about use of violence } \\
(-) ; \text { Empathy: } \mathrm{ns} \text {; Trait-anger: } \mathrm{ns} \text {; Anger expression }{ }^{* *}(-) ; \text { Impulsivity** }(-) ; \\
\text { Self-esteem }{ }^{* *}(+) ; \text { Symptomatology }\end{array}$ \\
\hline Echeburúa et al. ${ }^{40(4)}$ & $\begin{array}{l}\text { Quasi-experimental } \\
\text { (pre-test and post-test) } \\
\text { G1 = Completers } \\
\text { G2 = Dropout }\end{array}$ & $\begin{array}{l}\text { Success }=92 \% \\
\text { Cognitive bias about women }{ }^{* *}(-) \text {; Cognitive bias about use of violence }{ }^{* *} \\
(-) ; \text { Empathy: } \mathrm{ns} \text {; Symptomatology* (-); Hostility* (-); State-anger* }(-) \text {; } \\
\text { Impulsivity: } \mathrm{ns} \text {; Self-esteem: ns; Inadaptation: } \mathrm{ns} \text {; Motivation to change } \\
\left(\mathrm{G} 1^{*}(+) \text { x G2) }\right.\end{array}$ \\
\hline
\end{tabular}




\begin{tabular}{|c|c|c|}
\hline Echeburúa et al..$^{41}$ & $\begin{array}{l}\text { Experimental } \\
\text { (pre-test, post-test and 1, 3, } 6 \text { and } 12 \text { months } \\
\text { follow-up) }\end{array}$ & 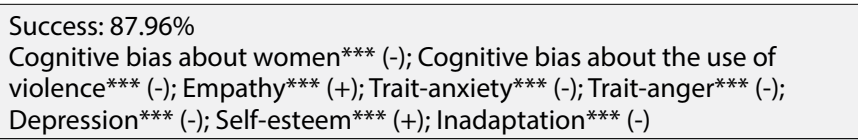 \\
\hline Authors & Research design & Results \\
\hline $\begin{array}{l}\text { Feder and Dugan }{ }^{42} \\
\text { (The Broward } \\
\text { experiment) }\end{array}$ & $\begin{array}{l}\text { Experimental } \\
\text { (pre-test and post-test) } \\
\mathrm{G} 1=\text { Experimental group } \\
\mathrm{G} 2=\text { Control }\end{array}$ & $\begin{array}{l}\text { Success }=97 \% \\
\text { Self-reports of abuse: } n s ; \text { Victim reports of abuse: } n s \\
\text { Recidivism (official reports): } n s \\
\text { Beliefs about wife beating, attitudes toward women, treats domestic } \\
\text { violence as a crime, responsibility, likelihood for repeated abuse: } n s\end{array}$ \\
\hline Lawson et al. ${ }^{43}$ & $\begin{array}{l}\text { Quasi-experimental } \\
\text { (pre-test and post-test) } \\
\text { G1 }=\text { Secure-changed } \\
\text { G2 = Secure-unchanged } \\
\text { G3 = Insecure }\end{array}$ & 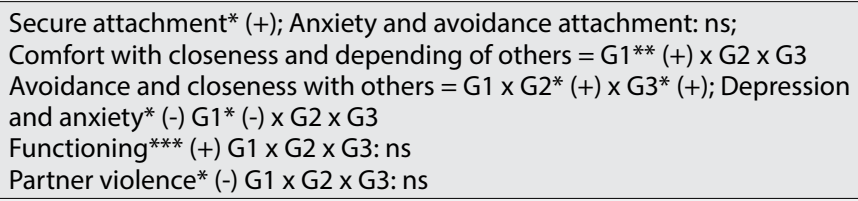 \\
\hline Lila et al. ${ }^{44}$ & Pre-test and post-test & $\begin{array}{l}\text { Perceived severity* (+) } \\
\text { Responsibility assumption* }(+) \\
\text { Risk of recidivism* (-) }\end{array}$ \\
\hline Lin et al. ${ }^{45}$ & $\begin{array}{l}\text { Quasi-experimental } \\
\text { (3, } 6 \text { and } 9 \text { months follow-up) } \\
\text { GC }=\text { Control }\end{array}$ & $\begin{array}{l}\text { Overall violence: GE* }(58.6 \%) \text { x GC (41.4\%) (3 months follow-up) } \\
\text { Physical violence: GE (20\%) x GC (13.4\%): ns } \\
\text { Verbal violence: GE* }(58.6 \%) \text { x GC (43.7\%) (3 months follow-up) }\end{array}$ \\
\hline $\begin{array}{l}\text { Novo et al. }{ }^{26} \text { (Galicia } \\
\text { Reeducation Program } \\
\text { for Gender Violence } \\
\text { Offenders) }\end{array}$ & $\begin{array}{l}\text { Quasi-experimental } \\
\text { (pre-test and post-test) }\end{array}$ & 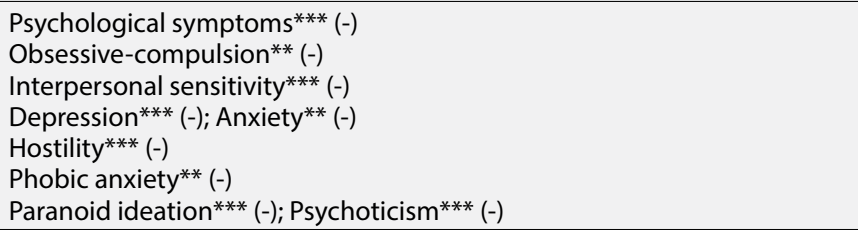 \\
\hline $\begin{array}{l}\text { Pascual-Leone et al. } .^{25} \\
\text { (Relating Without } \\
\text { Violence) }\end{array}$ & $\begin{array}{l}\text { Quasi-experimental } \\
\text { (7, } 8 \text { and } 9 \text { month, } 1,2 \text { and } 3 \text { years follow-up) } \\
\mathrm{GE}=\text { Intervention } \\
\mathrm{GC}=\text { Control }\end{array}$ & $\begin{array}{l}\text { Dropout }=10 \% \\
\text { Recidivism ( } 3 \text { years follow-up) }=15.6 \% \\
\text { GE* }(-) \text { x GC ( } 7 \text { and } 8 \text { months follow-up) } \\
\text { GE x GC: ns ( } 9 \text { months, } 1,2 \text { and } 3 \text { years follow-up) }\end{array}$ \\
\hline Ramírez et al. ${ }^{46}$ & $\begin{array}{l}\text { Quasi-experimental } \\
\text { (pre-test and post-test) } \\
\text { GE }=\text { Treatment } \\
\text { GC }=\text { Control }\end{array}$ & 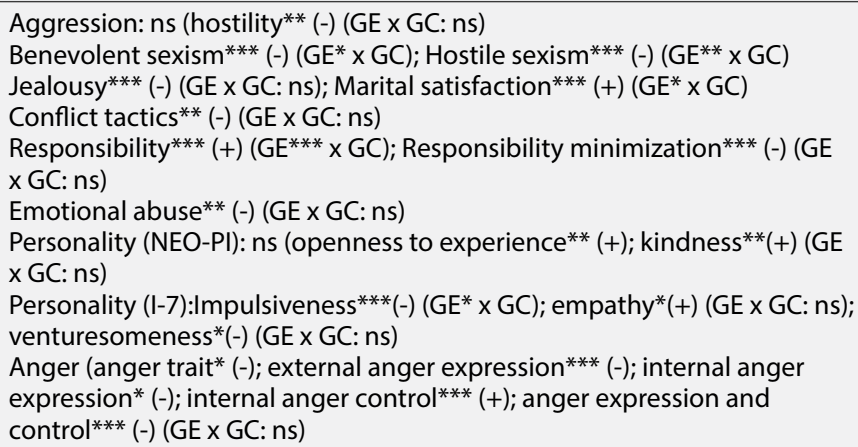 \\
\hline $\begin{array}{l}\text { Rosenbaum et al. }{ }^{47} \\
\text { (Mens'Educational } \\
\text { Workshop - MEW) }\end{array}$ & $\begin{array}{l}\text { Quasi-experimental } \\
\text { (post-test and } 20 \text { months follow-up) } \\
\text { G1 = Self-referred } \\
\text { G2 = Court-referred } \\
\text { G3 }=\text { Completers } \\
\text { G4 }=\text { Non-completers } \\
7,10 \text { e } 20 \text { sessions }\end{array}$ & $\begin{array}{l}\text { Success } \\
\mathrm{G} 1(56.5 \%) \times \mathrm{G} 2^{* * *}(79.5 \%) \\
\mathrm{G} 1(39.4 \%) \times \mathrm{G} 2^{*}(75.2 \%) \text { (20 sessions) } \\
\text { Recidivism } \\
\mathrm{G} 1(13.4 \%) \times \mathrm{G} 2^{* *}(4.9 \%) \\
\mathrm{G} 3^{*}(-) \times \mathrm{G} 4 \\
10 \text { and } 20 \text { sessions }=>\text { recidivism }\end{array}$ \\
\hline Sarto and Esteban ${ }^{48}$ & \begin{tabular}{|l|} 
Post-facto \\
(3,6 and 12 months follow-up) \\
\end{tabular} & Dropout $=55.1 \%$ \\
\hline Schmidt et al. ${ }^{49}$ & $\begin{array}{l}\text { Quasi-experimental } \\
\text { (pre-test and post-test) }\end{array}$ & $\begin{array}{l}\text { Success }=52 \% \\
\text { Statements that support abusive behaviour** }(-) \text {; Statements that } \\
\text { support a nonviolent relationship** }(+) \text {; Motivating factors for behaviour } \\
\text { change }^{* *}(+)\end{array}$ \\
\hline $\begin{array}{l}\text { Stith et al. } .^{50} \text { (Domestic } \\
\text { Violence Focused } \\
\text { Couples Treatment) }\end{array}$ & $\begin{array}{l}\text { Quasi-experimental } \\
\text { (pre-test and } 6 \text { month and } 2 \text { years follow-up) } \\
\text { T1 = Multi-couple group } \\
\text { T2 = Individual couple } \\
\text { T3 = Comparison }\end{array}$ & $\begin{array}{l}\text { Success } \\
\text { T1 (70\%) x T2 (73\%): ns } \\
\text { Beliefs about wife beating: } \mathrm{T} 1{ }^{* *}(-) \times \mathrm{T} 2 \times \mathrm{T} 3\left(\mathrm{M}^{* *}(-) \times \mathrm{W}\right) \\
\text { Marital satisfaction: } \mathrm{T} 1{ }^{* *}(+) \times \mathrm{T} 2 \times \mathrm{T} 3 \\
\text { Acceptance of marital aggression: } \mathrm{T} 11^{* *}(-) \times \mathrm{T} 2 \times \mathrm{T} 3 \\
\text { Recidivism } \\
6 \text { months: } \mathrm{T} 1(25 \%)^{*} \times \mathrm{T} 2(45 \%) \times \mathrm{T} 3(67 \%) \\
2 \text { years: } \mathrm{T} 2^{*}(0 \%) \times \mathrm{T} 3(50 \%) ; \mathrm{T}^{+}(13 \%) \times \mathrm{T} 3 ; \mathrm{T}^{*} \times \mathrm{T} 2^{+}\end{array}$ \\
\hline $\begin{array}{l}\text { Taylor et al. }{ }^{51} \text { (Victim } \\
\text { Services' Alternatives } \\
\text { to Violence) (The } \\
\text { Brooklyn Experiment) }\end{array}$ & $\begin{array}{l}\text { Experimental } \\
\text { (6 and } 12 \text { months follow-up) } \\
\mathrm{GE}=\text { Intervention } \\
\mathrm{GC}=\text { Control }\end{array}$ & $\begin{array}{l}\text { Recidivism } \\
\text { Officially recorded incidents: GE** (-) x GC } \\
\text { Victim-reported incidents: GE (-) x GC: } \mathrm{ns} \\
\text { Treatment }=<\text { recidivism }\end{array}$ \\
\hline
\end{tabular}




\begin{tabular}{|c|c|c|}
\hline Authors & Research design & Results \\
\hline $\begin{array}{l}\text { Alexander }{ }^{53} \text { (Stages } \\
\text { of change - SOC; } \\
\text { Cognitive-behavioural } \\
\text { gender-re-education } \\
\text { format - CBTGR) }\end{array}$ & $\begin{array}{l}\text { Quasi-experimental (pre-test, post-test and } 6 \\
\text { and } 12 \text { months follow-up) } \\
\text { G1 }=\text { SOC } \\
\text { G2 }=\text { CBTGR }\end{array}$ & $\begin{array}{l}\text { Physical and psychological aggression (post-test): ns } \\
\text { Physical aggression (follow-up) (-) (G1* x G2) } \\
\text { Psychological aggression (follow-up) (-) (G1 x G2: ns) } \\
\text { Assumption of responsibility, attendance, treatment completion, } \\
\text { working alliance, group cohesion: } n s\end{array}$ \\
\hline $\begin{array}{l}\text { Dunford }{ }^{54} \\
\text { (San Diego Navy } \\
\text { Experiment) }\end{array}$ & $\begin{array}{l}\text { Randomized experimental (post-test and } 1 \text { year } \\
\text { follow-up) } \\
\text { T1 = Men's group } \\
\text { T2 - Conjoint group } \\
\text { T3 = Rigorous monitoring group } \\
\text { T4 = Control group }\end{array}$ & $\begin{array}{l}\text { Success }=71 \% \\
\text { Frequency of victimization: T1 } 1 \text { T } 2 \text { × T3 } 3 \text { T4: ns } \\
\text { Official data: } \mathrm{T} 1 \times \mathrm{T} 2 \times \mathrm{T} 3 \times \mathrm{T} 4 \text { : } \mathrm{ns} \\
\text { Prevalence and frequency of violence* }(-)\end{array}$ \\
\hline $\begin{array}{l}\text { Hendricks et al. }{ }^{24} \\
\text { (Stopping Abuse for } \\
\text { Everyone - SAFE; } \\
\text { Reasoning and } \\
\text { Rehabilitation - R\&R) }\end{array}$ & $\begin{array}{l}\text { Quasi-experimental }(6,12 \text { and } 18 \text { months } \\
\text { follow-up) } \\
\text { G1 }=\text { SAFE } \\
\text { G2 }=\text { R\&R }+ \text { SAFE } \\
\text { G3 }=\text { Completed SAFE } \\
\text { G4 }=\text { Incomplete SAFE }\end{array}$ & 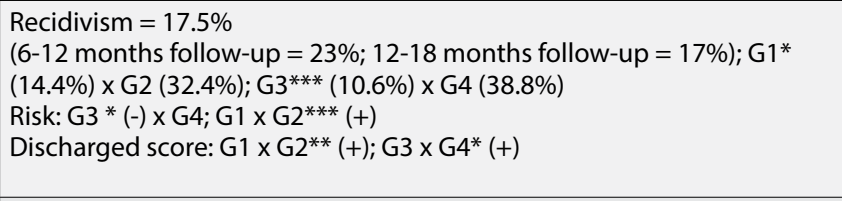 \\
\hline Morrell et al. ${ }^{55}$ & $\begin{array}{l}\text { Quasi-experimental (pre-test, post-test and } 6 \\
\text { month follow-up) } \\
\text { T1 = Cognitive-behavioural group therapy } \\
\text { T2 = Supportive group therapy }\end{array}$ & $\begin{array}{l}\text { Success }=86 \% \\
\text { Recidivism: } \mathrm{ns} \\
\text { Physical assault } \\
\text { coercion* }^{*}(-): \mathrm{T} 1 \times \mathrm{T} 2 \text { : } \mathrm{ns} \\
\text { Readiness to change: } \mathrm{ns}(\mathrm{T} 1 \times \mathrm{T} 2: \mathrm{ns}) \\
\text { Self-esteem }{ }^{* *}(+)(\mathrm{T} 1 \times \mathrm{T} 2: \mathrm{ns}) \\
\text { Self-efficacy }^{* * *}(+)\left(\mathrm{T} 1 \times \mathrm{T} 2^{*}\right)\end{array}$ \\
\hline Murphy et al. ${ }^{56}$ & $\begin{array}{l}\text { Quasi-experimental (pre-test and post-test) } \\
\text { T1 = Cognitive-behavioural } \\
\text { T2 = Compassion workshop }\end{array}$ & $\begin{array}{l}\text { Self-esteem: } 1^{*}(+) \times \mathrm{T} 2^{* * *}(+) \\
\text { Physical aggression: } 1^{*}(-) \times \mathrm{T} 2^{* *}(-)\end{array}$ \\
\hline
\end{tabular}

by Pascual-Leone et $a l .{ }^{25}$, based on emotion-focused therapy, eye movement desensitization and reprocessing and imago couples therapy, presented inconsistent results: at the 7 and 8 months followup the individuals who participated in the intervention revealed lower recidivism rates than control group; however, at the 9 months, 1, 2 and 3 years follow-up such differences were less evident.

Regarding comparative studies, Alexander's ${ }^{53}$ study that compared individuals who participated in a cognitive behavioural intervention with individuals that participated in a stages of change intervention, only revealed differences between the groups in physical violence. In the same study, participants of cognitivebehavioural group were those who presented less abusive behaviours at the follow-up assessment. To what concerns the other dimensions analysed no differences between the groups were found. On the other hand, the study of Hendricks et $a .^{24}$, that compared a psychoeducational program with other program that requires the participation of the offender in an psychoeducational program and in a cognitive program, revealed significant differences between groups. Individuals that participated only in the psychoeducational program had lower recidivism rates, whereas individuals who participated in both programs revealed higher risk levels. In the same sense, the study of Morrel et al. ${ }^{55}$, that compared individuals that participated in a cognitive behavioural intervention with individuals who attended a support group, showed differences between the groups only in self efficacy, being the participants of support group the ones who presented higher scores. The study of Scott et al..$^{57}$ also revealed that resistant participants that attended an intervention program based on motivational interview followed by ten weeks of a standard program, showed a lower probability to dropout than resistant individuals that attended only the standard program. The other studies ${ }^{54,56}$ did not reveal significant differences between the groups.

\section{Discussion}

The analysis of the literature about batterers' intervention reveals a proliferation of studies on intervention effectiveness assessment. These results allow to prove the growing attention and interest given to this phenomenon. However, such interest is not equal in the different geographical areas since there is an overrepresentation of countries of North America (USA and Canada). However, in the last years European countries such as England or Spain have made positive efforts on this matter.

Regarding the program's objectives, they focus essentially in the promotion of skills, in anger reduction, in ending abusive behaviour, in education about domestic violence and in the accountability for the use of violence. In general, these objectives reveal consistency with the main standards for batterer intervention ${ }^{8,58-62}$. This proves that, despite the criticism, the majority of the intervention programs consider the standards relevant.

To what concerns effectiveness assessment, results revealed rates of recidivism ranging from $0 \%$ and $65.9 \%$, which is consistent with previous analysis ${ }^{17,18}$. Intervention programs also revealed positive results on the perpetration of violence against the intimate partner, attitudes toward violence and/or women, anger and psychological symptomatology. On the other hand, $30 \%$ of the studies did not show significant effects of the treatment. These findings suggest that results concerning batterer intervention efficacy remain controversial. Although some intervention programs assess dimensions of batterer functioning, the most part of the identified papers focused on the analysis of success rates, recidivism and violent behaviours against the intimate partner, omitting other important variables, namely the personal and social skills. And, although such dimensions were addressed by a considerable percentage of programs, they were not assessed or identified as a success criterion. Moreover, the previous revisions ${ }^{22,66}$ and meta-analysis ${ }^{13,17,18}$ on batterer intervention efficacy only focused on recidivism rates. So, the inclusion of other success indicators is an important contribution of the present review. In fact, according to Novo et al. ${ }^{26}$, who stated that programs that simultaneously promote skills and focus on the 
internal mechanisms underlying violence (i.e. self-esteem, problem solving, communicational skills) are more effective in recidivism prevention, the assessment of dimensions addressed during the intervention are of extreme relevance. Different studies revealed that batterers' assessment should be multidimensional, using different sources and centred in different dimensions ${ }^{21,30,63}$. Assessments based only in recidivism led to a reducibility of intervention programs. Furthermore, although the decrease of recidivism is an objective of main importance, regarding the personal and social costs of intimate partner violence, the assessment of other dimensions and variables that are mitigating the potential effects of intervention are crucial ${ }^{18}$. The previously referred dimensions assume not only an important role in intimate partner violence risk, but also in terms of program validity, in order to analyse if the program addresses the dimensions that it claims to address.

Results from this revision also allow concluding that regarding the intervention model and the intervention format, the most part of the programs adopted a cognitive-behavioural or a psychoeducational (Duluth model) group model. The identified programs sustain strategies such as time-out, cognitive restructuring, skills training, muscular relaxing and feedback. However, the studies that assessed intervention programs based on other intervention models ${ }^{25,43,50}$ also revealed positive results in terms of efficacy. Furthermore, other studies that compared programs based on different intervention models ${ }^{55,56}$ did not show significant differences among them. In fact, these results are consistent with Arias et al. ${ }^{18}$ findings, showing that programs based on intervention models different from Duluth and cognitive-behavioural have a significantly positive effect. However, it is important to note that some of the programs included in the present analysis also integrate strategies from cognitive-behavioural models ${ }^{43,54}$. Additionally, some of these studies revealed other weaknesses: small sample dimentions ${ }^{43}$, research design ${ }^{26,30,33,34,39,64}$ and sample specificities ${ }^{50,54}$. For instance, concerning the sample, the program described by Dunford ${ }^{54}$ was implemented in a sample of perpetrators that belong to the Navy, which difficult the generalization of the results. On the other hand, the program exposed by Stith et al. ${ }^{50}$ was based on a sample of couples whose "men who would be considered 'batterers' or who had on-ongoing substance abuse problems were excluded from the program" (p. 316). So, in our opinion, results from this program cannot be compared to other programs implemented with batterers, since the sample only included minor violence forms. It should be noted that the authors of the referred study warned to the potential damages associated with the couples approach, suggesting that this model should only be implemented in couples whose violence is less severe and with who choose voluntarily to stay together. So, couples therapy continues to raise a number of doubts and questions.

On the other hand, the batterers' typology/sample and the context where the programs were implemented can also constrain its results. The analysed programs are directed to distinct batterers (i.e. self-referred and court referred), with different risk levels (i.e. low, moderate and high risk) and implemented in distinct contexts (i.e. community, prisons, hospitals). In fact, there are specific characteristics associated with each perpetrator/sample ${ }^{65}$ and with different contexts, so the results found in one sample or intervention context cannot be applied to other samples or distinct contexts. At the same point, it is likely that individuals connected with the judicial system present response styles different from self-referred men, since the last ones know that the information obtained during the assessment will not be used in a punitive manner ${ }^{65}$.

Despite the proliferation and expansion of intervention programs for batterers, different studies have produced variable and contradictory results. If, on one hand, some programs show positive results $^{26,27,32,33,35,37,39,43,47}$, others do not reveal significant differences between the group that participated in the intervention and the group that did not receive intervention ${ }^{20,28,42,52,54}$. Some authors state that mixed results are due to either differences in terms of indicators and measures used in the assessment ${ }^{17,22,66,65}$ or the success and efficacy definition ${ }^{67}$. In the analysed studies there is a multitude of parameters and assessment measures that can constrain the assessment of the efficacy. In the same sense, the studies analysed here differ regarding the measures used in the recidivism assessment: some used the perpetrators report, others used the victims' reports and others used the official data, which can lead to discrepant results, since different measures produce different results.

Moreover, from a methodological point of view, the studies were fairly heterogeneous which can explain the contradictory data. For example, even though the majority of the studies stated the use of a quasi-experimental design, in fact the design was not a quasi-experimental one $26,29,30,33-35,37,39,64$. This happens because among the identified studies were found: (i) studies without a control group $29,33,35,40$; (ii) studies that assessed the effectiveness after the ending of the treatment (post-test design) ${ }^{36,45,48}$; (iii) studies that used

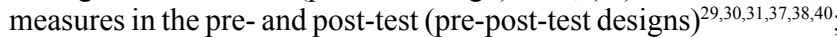
and (iv) studies with a non-equivalent control group ${ }^{20,27,31}$. Moreover, the programs without a control group did not provide a reference point in order to assess their effectiveness. Also, studies with preand post-test designs that revealed a reduction in recidivism may be questionable since there is evidence showing that violence decreases after police intervention ${ }^{52}$ and that a considerable number of perpetrators stop their abusive behaviours without any intervention ${ }^{65}$. Lastly, individuals who complete the intervention program are not comparable to those who do not complete the intervention ${ }^{66}$.

It is important to note that the eclectic nature of the intervention programs may also explain the contradictory results. The analysed studies revealed great variability in terms of program duration and the different standards are, in part, responsible for this variability.

Although our research in the main social sciences databases was inclusive, there are some limitations in the present study: research constrains (e.g. 12 years period, inclusion of studies in Spanish and English), leaving out other studies; exclusion of non-indexed international studies, dissertations and book chapters; inclusion of different research designs and inclusion of studies with different samples.

Another limitation of this review is the absence of qualitative literature about change among batterers. This type of research can help to explain the change process and the men's perception about intervention and about their own changes. Qualitative research could also help to improve the design of new interventions, to respond more effectively to domestic violence.

\section{Conclusion}

In summary, the results obtained in this revision allow to corroborate the assumption that associated with batterer intervention programs is a lot of controversy, since its construction (theoretical model, intervention format, objectives), its implementation (context of implementation, sample) and assessment (research design, assessed dimensions) differ. Another question concerns the intervention effectiveness, in other worlds, the results from different researches continue to point in opposite directions. Despite the unclear results about intervention efficacy it is crucial an accurate interpretation of the significant effect of the intervention programs. Different authors ${ }^{17,25}$ sustain that small effects in recidivism reduction can represent a considerable social impact, especially for the victims. This finding is especially relevant given the social, legal and public health costs associated with intimate partner violence ${ }^{68}$.

In this sense, and despite the controversial results about batterer intervention effectiveness, it is important to emphasize the relevance of the development and implementation of re-education programs about domestic violence, to reduce the recidivism and to protect the victims.

\section{Acknowledgment}

The first author of this manuscript is recipient of a Fundação para a Ciência e Tecnologia (FCT, Portugal) fellowship, with the reference SFRH/BD/66110/2009. 


\section{References}

1. Ansara DL, Hindin MJ. Psychosocial consequences of intimate partner violence for women and men in Canada. J Interpers Violence. 2011;26(8):1628-45.

2. Campbell JC. Health consequences of intimate partner violence. Lancet. 2002;359(9314):1331-6.

3. Coker AL, Smith PH, Bethea L, King M, McKeown RE. Physical health consequences of physical and psychological intimate partner violence. Arch Fam Med. 2000;9:451-7.

4. Ansara DL, Hindin MJ. Psychosocial consequences of intimate partner violence for women and men in Canada. J Interpers Violence. 2011;26(8):1628-45.

5. World Health Organization (WHO). WHO multi-country study on women's health and domestic violence against women: initial results on prevalence, health outcomes and women's response. Genève: WHO Publications; 2005.

6. World Health Organization (WHO). Global and regional estimates of violence against women: prevalence and health effects of intimate partner violence and non-partner sexual violence. Genève: WHO Publications; 2013.

7. Lisboa M. Violência de género: vitimação de mulheres e homens. In: Lisboa M, Barroso Z, Patrício J, Coelho A, coordenadores. Violência e género: inquérito nacional sobre a violência exercida contra mulheres e homens. Lisboa: Comissão para a Igualdade e Cidadania; 2009. p. 55-64.

8. Bennett LW, Williams OJ. Intervention programs for men who batter. In: Renzetti CM, Edleson JL, Bergen RK, editors. Sourcebook on violence against women. Thousand Oaks: Sage; 2001. p. 261-77.

9. Bowen E. The rehabilitation of partner-violent men. Oxford: Wiley-Blackwell; 2011.

10. Coulter M, VandeWeerd C. Reducing domestic violence and other criminal recidivism: effectiveness of a multilevel batterers intervention program. Violence Vict. 2009;24(2):139-52.

11. Mederos F. Changing our vision of intervention - The evolution of programs for physically abusive men. In: Adarondo E, Mederos F, editors. Programs for men who batter: intervention and prevention strategies. Kingston: Civic Research Institute; 2002. p. 1-1, 1-26.

12. Manita C. Estudo preliminar de caracterização da intervenção com agressores no contexto da violência em Portugal. Lisboa: Comissão para a Igualdade e para os Direitos das Mulheres, Presidência do Conselho de Ministros; 2005.

13. Feder L, Wilson DB. A meta-analytic review of court-mandated batterer intervention programs: can courts affect abusers' behaviour? J Exp Criminol. 2005;1(2):239-62.

14. Tolman RM, Edleson JL. Intervention for men who batter: a review of research. In: Stith SR, Straus MA, editors. Understanding partner violence: prevalence, causes, consequences and solutions. Minneapolis: National Council on Family Relations; 1995. p. 262-73.

15. Dalton B. What's going on out there? A survey of batterer intervention programs. Journal of Aggression, Maltreatment \& Trauma. 2007;15(1):59-74.

16. Feder $\mathrm{L}$, Wilson DB. Mandated batterer intervention programs to reduce domestic violence. In: Welsh BC, Farrington DP, editors. Preventing crime: what works for children, offenders, victims, and places. Dordrecht: Springer; 2007. p. 131-45.

17. Babcock JC, Green CE, Robie C. Does batterers' treatment work? A meta-analytic review of domestic violence treatment. Clin Psychol Rev. 2004;23(8):1023-53.

18. Arias E, Arce R, Vilariño M. Batterer intervention programes: a meta-analytic review of effectiveness. Psychos Interv. 2013;22(2):153-60.

19. Gondolf EW. Batterer treatment systems: issues, outcomes, and recommendations. Thousand Oaks: Sage; 2002.

20. Bowen E, Gilchrist EA, Beech AR. An examination of the impact of community-based rehabilitation on the offending behavior of male domestic violence offenders and the characteristics associated with recidivism. Legal and Criminological Psychology. 2005;10(2):189-209.

21. Gondolf EW. Evaluating batterer counselling programs: a difficult task showing some effects and implications. Aggress and Violent Behavior. 2004;9(6):605-31.

22. Davis RC, Taylor BG. Does batterer treatment reduce violence? A synthesis of the literature. Women \& Criminal Justice. 1999;10(2):69-93.
23. Rosenfeld BD. Court-ordered treatment of spouse abuse. Clin Psychol Rev. 1992;12(2):205-26.

24. Hendricks B, Werner T, Shipway L, Turinetti GJ. Recidivism among spousal abusers: predictions and program evaluation. J Interpers Violence. 2006;21(6):703-16.

25. Pascual-Leone A, Bierman R, Arnold R, Stasiak E. Emotion-focused therapy for incarcerated offenders of intimate partner violence: a 3-year outcome using a new whole-sample matching method. Psychother Res. 2011;21(3):331-47.

26. Novo M, Fariña F, Seijo D, Arce R. Assessment of a community rehabilitation programme in convicted male intimate-partner violence offenders. Int J Clin Health Psychol. 2012;12(2):219-34.

27. Bowen E. Therapeutic environment and outcomes in a U.K. domestic violence perpetrator program. Small Group Research. 2010;41(2):198220.

28. Bowen E, Gilchrist EA, Beech AR. Change in treatment has no relationship to subsequent reoffending in UK domestic violence sample: a preliminary study. Int J Offender Ther Comp Criminol. 2008;52(5):598-614.

29. Buttell FP. Exploring the relevance of moral development as a treatment issue in batterer intervention. Social Work Research. 2003;27(4):232-41.

30. Buttell FP, Carney MM. A multidimensional assessment of a batterer treatment program: an alert to a problem? Res Soc Work Pract. 2004;14(2):93-101.

31. Buttell FP, Carney MM. Do batterer intervention programs serve African American and Caucasian batterers equally well? Investigation of a 26week program. Res Soc Work Pract. 2005;15(1):19-28.

32. Buttell FP, Carney MM. Large sample evaluation of a court-mandated batterer intervention program: investigating different program effect for African American and Caucasian men. Res Soc Work Pract. 2006;16(2):121-31.

33. Buttell FP, Pike CK. Investigating the differential effectiveness of batterer treatment program on outcomes for African American and Caucasian batterers. Res Soc Work Pract. 2003;13(6):675-92.

34. Carney MM, Buttell F. Exploring the relevance of interpersonal dependency as a treatment issue in batter intervention. Res Soc Work Pract. 2006;16(3):276-86.

35. Chan KL. Group therapy for male batterers: a Chinese experience. Social Work with Groups. 2004;26(4):79-90.

36. Cissner AB, Puffett NK. Do batterer program length or approach affect completion or re-arrest rates? A comparison of outcomes between defendants sentenced to two batterer programs in Brooklyn. New York: Center for Court Innovation; 2006.

37. Connors AD, Mills JF, Gray AL. An evaluation of intimate partner violence intervention with incarcerated offenders. J Interpers Violence. 2012;27(6):1176-96

38. Connors AD, Mills JF, Gray AL. Intimate partner violence intervention for high-risk offenders. Psychol Serv. 2013;10(1):12-23.

39. Echeburúa E, Fernández-Montalvo J. Evaluación de un programa de tratamiento en prisión de hombres condenados por violencia grave contra la pareja. Int J Clin Health Psychol. 2009;9(1):5-20.

40. Echeburúa E, Fernández-Montalvo J, Amor PJ. Psychological treatment of men convicted of gender violence: a pilot study in Spanish prisons. Int J Offender Ther Comp Criminol. 2006;50(1):57-70.

41. Echeburúa E, Sarasua B, Zubizarreta I, Corral P. Evaluación de la eficacia de un tratamiento cognitivo-conductual para hombres violentos contra la pareja en un marco comunitario: una experiencia de 10 años (19972007). Int J Clin Health Psychol. 2009;9(2):199-217.

42. Feder L, Dugan L. A test of the efficacy of court-mandated counseling for domestic violence: the Broward experiment. Justice Quarterly. 2002;19(2):343-75.

43. Lawson DM, Barnes AD, Madkins JP, Francios-Lamonte BM. Changes in male partner abuse attachment styles in group treatment. Psychotherapy (Chic). 2006;43(2):232-7.

44. Lila M, Oliver A, Galiana L, Gracia E. Predicting success indicators of an intervention programme for convicted intimate-partner violence offenders: the Contexto programme. Eur J Psychol Appl Leg Context. 2013;5(1):73-95.

45. Lin S, Su C, Chou FH, Chen S, Huang J, Wu GT, et al. Domestic violence recidivism in high-risk Taiwanese offenders after the completion of violence treatment programs. J Forensic Psychiatry Psycol. 2009;20(3):458-72. 
46. Ramírez MP, Framis AG, Espinosa MJ. Evaluación de la eficacia del tratamiento con agresores de pareja (PRIA) en la comunidad. Psychosoc Interv. 2013;22(2):105-14.

47. Rosenbaum A, Gearan PJ, Ondovic C. Completion and recidivism among court and self-referred batterers in a psychoeducational group treatment program. J Aggress Maltreat Trauma. 2001;5(2):199-220.

48. Sarto SB, Esteban PJ. Psicopatología, características de la violencia y abandonos con la pareja: resultados en un dispositivo de intervención. Psicothema. 2010;22(4):593-9.

49. Schmidt MC, Kolodinsky JM, Carsten G, Schmidt FE, Larson M, MacLachlan C. Short term change in attitude and motivating factors to change abusive behavior of male batterers after participating in a group intervention program based on the pro-feminist and cognitive-behavioral approach. J Fam Violence. 2007;22:91-100.

50. Stith SM, Rosen KH, McCollum EE, Thomsen CJ. Treating intimate partner violence within intact couple relationships: outcomes of multi-couple versus individual couple therapy. J Marital Fam Ther. 2004;30(3):305-18.

51. Taylor BR, Davis RC, Maxwell CD. The effects of a group batterer treatment program: a randomized experiment in Brooklyn. Justice Quarterly. 2001;18(1):171-201.

52. Taylor BG, Maxwell CD. The effects of a short-term batterer treatment program for detained arrestees: a randomized experiment in the Sacramento County, California Jail. Washington: National Institute of Justice, Office for Justice Programs, U.S. Department of Justice; 2009.

53. Alexander PC. Stages of change and the group treatment of batterers. Washington: U.S. Department of Justice, National Institute of Justice; 2009.

54. Dunford F. The San Diego Navy experiment: an assessment of interventions for men who assault their wives. J Consult Clin Psychol. 2000;68(3):468-76.
55. Morrel TM, Elliott JD, Murphy CM, Taft CT. Cognitive behavioral and supportive group treatments for partner-violent men. Behav Ther. 2003;34(1):77-95.

56. Murphy CM, Stosney S, Morrel TM. Change in self-esteem and physical aggression during treatment for partner violent men. J Fam Violence. 2005;20(2):201-10.

57. Scott K, King C, McGinn H, Hosseini N. Effects of motivational enhancement on immediate outcomes of batterer intervention. J Fam Violence. 2011;26(2):139-49.

58. Adams D, Cayouette S. Emerge - A group education model for abusers. In: Adarondo E, Mederos F, editors. Programs for men who batter: intervention and prevention strategies. Kingston: Civic Research Institute; 2002. p. 4-1, 4-32.

59. Aldarondo, E, Mederos F. Common practitioners' concerns about abusive men. In: Aldarondo E, Mederos F, editors. Programs for men who batter: intervention and prevention strategies. Kingston: Civic Research Institute; 2002. p. 2-1, 2-20.

60. Maiuro RD, Hagar TS, Lin HH, Olson N. Are current state standards for domestic violence perpetrator treatment adequately informed by research? A question of questions. J Aggress Maltreat Trauma. 2001;5(2):21-44.

61. Murphy CM. Toward empirically based standards for abuser intervention: the Maryland model. J Aggress Maltreat Trauma. 2001;5(2):249-64.

62. Rosenbaum A, Leisring PA. Group intervention programs for batterers. J Aggress Maltreat Trauma. 2001;5(2):57-71.

63. Eckhardt C, Murphy C, Black D, Suhr L. Intervention programs for perpetrators of intimate partner violence: conclusions from a clinical research perspective. Public Health Rep. 2006;121(4):369381.

64. Schmidt D. Essential elements and standards for batterer intervention programs. Topeka: Kansas Attorney General; 2012. 